\title{
Prison, Stigma, Discrimination and Personality as Predictors of Criminal Recidivism: Preliminary Findings
}

\author{
Aminu Musa Ahmed, Abd Halim B. Ahmad \\ Bayero University, Kano, Nigeria \\ Universiti Utara Malaysia, Malaysia \\ aminmusaahmed@gmail.com
}

\begin{abstract}
Criminal recidivism as a contemporary and global phenomenon has been explained and analysed from different perspectives. The aim of this study is to determine the predictors of criminal recidivism using four main constructs as predictors: prison; stigma; discrimination; and personality among the ex-prisoners in metropolitan Kano-Nigeria. Data was gathered using qualitative method (indepth interviews) from the ex-prisoners and analysed using narrative analysis method. The results from the qualitative analysis revealed that prison, stigma and discrimination were found to have effects on criminal recidivism as the respondents revealed base on their experiences and it is also revealed that such predictors if experienced can give a room for further reoffending whereas personality as predictor was found not have much impact on recidivism among the ex-prisoners in metropolitan Kano-Nigeria. Thus, it was concluded that three (prison, stigma and discrimination) out of the four constructs used can predicts and determine criminal recidivism among the ex-prisoners in metropolitan Kano-Nigeria.
\end{abstract}

Keywords: Prison, Stigma, Discrimination, Personality, Recidivism

\section{Introduction}

The re-integration of the released inmates into the society from the prison institution poses a great challenges to almost all societies globally (Travis et al., 2001; Farrall and Sparks, 2006; Wartna and Nijssen, 2006) and breeds the phenomenon of recidivism. Criminal recidivism is considered to be one of the most contemporary issues especially within the context of criminal justice system. Many researches were conducted on criminal recidivism and they have analysed various possible predictors of offenders' recidivism these include for instance, static and dynamic factors (Gendreau et al., 1996); age (first arrest), criminal versatility, substance abuse (Hare, 1999); time spent under prison custody (Meade et al., 2012); previous arrest and convictions (Langan and Lenin, 2002); individual race (Wehrman, 2010; Steen and Opsal, 2007); being young (Huebner and Berg, 2011); gender of the offender as a predictor (Makarious et al., 2010); communication approach (Koschmann and Peterson, 2013); Subjective and Social approach(Lebel et al., 2008; Davis et al., 2012 ); Educational Attainment and Peer Group Influence (Tenibiaje, 2013); Moral Development(Vugt et al., 2011); among others. Never, the less the phenomenon is still a concurrent one with many ex-prisoners are taken back to custody as criminal recidivists. This study intend to look at the phenomenon of criminal recidivism in metropolitan Kano-Nigeria among the ex-prisoners taking into account the role of prison and its effects, the effect of stigma, discrimination as well as the effects of personality on criminal recidivism.

Problem Statement: The phenomenon of criminal recidivism poses a great threat to the state, communities as well as the individuals generally. It is established that ex-prisoners experience societal rejection and labelling, because many people may not freely interact with them. They are treated badly with all sorts of stigmatization and discrimination in the society (Madaki, 2011). Institutionally, the prison institution is considered to be no longer effective in correction instead it has become just a mare 'society of captives' (Clemmer, 1940; Skyes,1958) and avenue for learning more criminality which negates the propositions of specific deterrence theory that punishment certainty and severity can reduce reoffending and this supported the propositions of labeling theory (Lemert, 1972) in the sense that, the institution (prison) simply increases the chances and exposure to criminogenic tendencies on the inmates, that is, the inmates are simply confined in another 'school of crime' which by implication make them to endure all the stress, they are also cut off from their societal social attachment, they are labelled and stigmatized base on their new status among others. Thus, the theory stressed that the combination of all these negative tendencies could invariably foster hatred, anger, anxiety and thereby creates a scenario of defiance (Francis et al., 2011) and recidivism (Cid, 2009). Moreover, strictness and punitiveness of 
prison institution could lead to high level of criminal recidivism and perhaps it may also predisposes human resource depreciation and negation in terms of labour for the offenders (Waldfogel, 1994) harsh prison measures would therefore only succeeded in establishing criminogenic effects(Nagin, et al., 2009; Di Tella and Schargrodsky, 2010).

Equally, from the personality point of view, it can be argued that, individual personal dispositions (Meade et al., 2012), pattern of behaviour (Savage, 2009) could pose a threat to individual behaviour especially towards offending and reoffending. The individual predispositions (pre-prison to post-prison) could lead to further offending. This can be channelled to individual's brain function, (Langevin and Curnoe, 2011) inability to adjust to individual personal gratification, aggression, (Mededovic et al., 2012) low level of individual mind and consciousness, frustration and absence of openness (Clower and Bothwell, 2001) could be associated with criminal behavioural pattern and reoffending. Therefore it is pertinent to note that, despite the fact that many predictors were used in the analysis of recidivism, but most of the predictors appeared to be skewed to one particular parameter of analysis. As such, this study is aimed at looking at the predictors from a wholistic point of view in the sense that societal reactions (social stigma and discrimination), the institutional aspect (prison) and the individual personal dispositions would be use as predictors of criminal recidivism. Thus, this study is set to achieve the following objectives:

- To identify the role of prison institution towards criminal recidivism among ex-prisoners in Kano;

- To determine whether or not social stigma can influence criminal recidivism among the exprisoners in Kano;

- To determine the influence of social discrimination of ex-prisoners on criminal recidivism;

- To find out if individual personality can have effect on criminal recidivism among ex-prisoners in metropolitan Kano.

\section{Methodology}

This study utilised ex-prisoners in metropolitan Kano-Nigeria as the population of the study. The study was qualitative and it utilizes qualitative approach to gather data. As such, data was collected using indepth (face to face) interviews. A total of six respondents (ex-prisoners) were used as respondents and purposive sampling method strategy was also used in the process. The purposive sampling method was used due to the nature of the target population who are not easy to be contacted without personal contact. Thus, the respondents were identified using personal contact. Though, at the initial stage they refused to grant the interview but after repeated efforts they were convinced that, the interview was for the academic purpose only and they granted the interview. Five of the respondents were males and only one among them was a female. Moreover, narrative technique of analysis was used to interpret and analysed the interview results.

\section{Findings and Discussion}

This study aimed at analysing the predictors of criminal recidivism among the ex-prisoners in metropolitan Kano-Nigeria. Four (4) main themes were used for the interview: prison; stigma; discrimination and personality. Thus, the narrative analysis was base on such themes as interviewed.

Prison: Under this theme respondents were asked about their experiences in terms of living condition in the prison, possibilities to learn crime, tendency to go back and whether they received any support and training while in the custody. According to one of the respondents;

During my time there, there was no clean water, no mattress, no good food or medicine. If you see our food you will cry! We use one toilet and we are more than one hundred

Furthermore, a female respondent corroborate the above assertion;

Though, we are being kept in separate rooms from the men, and we are not many as the men inmates, but the environment there is hell; there is nothing to cater for your health in the prison.

In terms of the possibilities of learning more criminal technique, majority of the respondents lament that it is quite easy and possible to do that. According to one of the respondents;

We meet with different category of criminal some are very dangerous when you compare your offence with their offence. So from there you would develop feelings that you are not even a good criminal and as a result of your interaction with such inmates you learn other criminalities 
Another respondent also maintained that;

In prison it is very easy to learn crime. You see, we were taken to a place with more harden criminals and in my case I stay in prison for good three (3) years with such people

On the issue of returning to prison the respondents maintained that;

Yes of course, there could be that tendency, because some people may prefer to go back to prison than to face such a humiliation outside the prison: our society is not supportive enough as such going back to prison may sometimes not be a problem for some of us

While commenting on the same issue a female respondent stressed that;

I have no regretted what so ever and I am not afraid of going back to prison anymore: people do not welcome us; they hate us; they see us as completely bad just because of one mistake or the other. So I personally do not fear of prison any more

On the issue of support and training the respondents a respondent revealed that;

There is no any support from the prison staff, there is nothing like training. They always shout at us, we always had disagreement with the staff, they see us criminals and bad people

Also another respondent comment that;

If anybody tells you that there is support or training in prison he is only deceiving you. There is nothing as such, no provision for vocational skill, education, or any other type of support

Stigma: Social stigma is a situation where by the society labelled and tainted an individual with inferiority manner base on particular status or social circumstances. According to ex-prisoners interviewed on stigma;

In this society people do really stigmatized us, once you have been to prison that denting image of stigma that would spoil your identity would be enforced on you by the society

Also commenting on her experience on stigma, a female respondent state that;

Yes it is very clear and common to have yourself being alienated in this society simply because you have been to prison...in fact this can be easier for men(ex-prisoners) but for somebody like me (a female) my fellow women folk do alienated me clearly.

According to another respondent;

You see once you are taken to prison, that would be the genesis of you being stereotyped as a bad person and if care is not taken, that would follow you through your life time

Another respondent revealed his experience of the consequences of stigma which results into rejection and discriminating him. He maintained that;

When you come back you have to get ready because people would prefer any other community member than you. Sometimes you would be discriminated against even in your immediate family

But for another respondent;

Sometimes somebody would prefer to remain in the prison than to come back and face this stigma and discrimination issue

In terms of social withdrawal from the community as a result of the stigma, the respondents stated that; To be frank with you I do not involve myself in many activities of my community...I prefer to be alone than to be labelled and stigmatized.

Another respondent further lament that;

People see you as outsider or somebody who is being considered dangerous so you have to withdraw from them in order to have your way...

Also another interviewee stated that; 
In most cases we do leave our areas and relate with those that we met and became friends with them while we are in prison.

Discrimination: Discrimination of ex-prisoners is considered to be an offshoot of social stigma (Goffman, 1963). Generally, the perception of discrimination can be seen as a verdict that an individual has experienced one form of rejection, unequal, or unfair treatment because of being a member that belong to a particular disadvantaged social group (Kaiser \& Major, 2006) like the ex-prisoners. According to the respondents interviewed, they revealed that;

Ex-prisoners are discriminated all over the society simply because they have been to prison regardless of the gravity of the offence.

Another respondent posit that;

We are usually referred to as criminals; there is discrimination even in school, work place and sometimes in the neighbourhood or the community at large

A particular respondent who argued that he experience discrimination as a result of his criminal record revealed that;

Yes people like me (ex-prisoner) and who have criminal records are usually discriminated against; we are called name and we are being discriminated even in courts, police station or hospitals

Another respondent comment that;

There is discrimination among ex-prisoners because of our records (criminal) people have this belief that anybody who has been to prison for several time is completely bad and people will not associate with him, hence they would discriminate against you

Equally a respondent mentioned that;

Nobody wants to associate with me...in work places and school. In some cases, no body want to employ you, you can only get labourer work; the society made us to hate ourselves

Another respondent lament that;

...this discrimination is very common even within the family and when you come out to the larger society it is worst

But when they comment about discrimination from the point of ethnic background or race most of the respondents have no problem with such discrimination. They argued that;

To be honest with you discrimination is purely base on criminal records

Also commenting in this line, a respondent argued;

If not for our previous criminality, I don't think we can face such discrimination in school or working place

For another respondent;

Honestly, it has to do with your criminal record and your criminal history. People are always referring to your criminal history and based their discrimination against you base on that

Personality: Personality traits and personal disposition of an individual represent a particular behaviour pattern and some studies suggested that criminal recidivism could be associated with such pattern of behaviour (Savage, 2009). Thus, respondents were asked about their personality traits and how they behave. According to one of the respondents;

Well, the attitude of an individual is usually by birth but sometimes things can change for better or worst

Another respondents state that;

I don't care I do what I want to do. If anybody is having problem with that, that is his own problem!

For another respondent;

It is very common with me actually. I do get upset easily, I use to have a lot of tension sometimes; you know, small thing can make me to be angry with everybody around me.

Also another respondent posit that;

Sometimes, you will be excited it is normal, but sometimes you will not be 
A female respondent lament that;

All I know is my own feelings and my actions are towards my feelings, but for others I don't care because other people also are showing that they do not care about how you feel

Recidivism: Criminal recidivism in this study is used to examine the pattern of criminal reoffending by the ex-prisoners which would consequently lead to the re-conviction and subsequent re-incarceration of the ex-prisoner into the prison again. The respondents' perception on whether they are afraid to go back was asked through the interview. The respondent laments that;

I have no regrets what so ever and I am not afraid of going back to prison anymore: people do not welcome us; they hate us; they see us as completely bad just because of one mistake or the other. So I personally do not fear anything.

Another respondent while echoing the same position stated that;

I have been to prison for three (3) times now, there is nothing more to be afraid of again.

Another respondent stressed that;

We are being mocked; ostracised; we are openly discriminated; and people do not even want us to go close to them. So what do you expect? This is why we feel we are not needed so there is no point even stopping the crime.

While commenting on reoffending, a respondent lament that;

You see if the societies continue with the way they are treating us I will also continue...the worst is prison and I do not fear to go there.

For another respondent;

I consider prison as my second home, so, if you take me there I know I will come out so I have no problem.

Another one state that;

It is our society that makes us to do what we are doing (crime) no body want to relate with you neither your family member nor other community members. If they keep on isolating us then that would give us reason to continue with our behaviour

\section{Discussion}

Prison: Prison is an institution that is meant to confine the offenders for violating the state laws. From the punishment point of view, it was emphasized that, prison is characterized with horrible and nasty experiences, and thus, the costs associated with imprisonment is said to reduce the usual utility of committing crime (Nagin et al., 2009). Offenders' knowledge of the certainty that such sanctions of prison will be imposed on them and on the other hand, the severity of such sanctions if they are imposed constitute the basis for offenders' calculation of the costs of committing criminal acts that are weighed with the benefits linked with such acts (Becker 1968; Grasmick and Bursick 1990). As such, imprisonment is perceived to be harsher and severe than noncustodial sanctions, and on the other hand, longer prison sentences are also alleged to be more severe than shorter prison sentences (Nagin et al., 2009; Nagin, 1998; Nagin et al., 2009). On the other hand scholars are of the view that despite the fact that prison as an institution is designed to correct and rehabilitate offenders but, prison is criminogenic and dehumanizing in nature due to experience of incarceration and the adaptation process through the prison subculture (Gendreau et al., 1999; Nagin et al., 2009).

Studies using Ethnographic characteristics of prison environments have portrayed inmate's culture while making an emphasis on the existing violence and antagonistic relationship toward legal authority that is being developed in reaction to the pains of prison life (Sykes 1958). However, some researchers are of the opinion that these sub cultural values are 'imported' into the prisons and simply replicate sub-cultural values that exists in lower class neighbourhoods (Irwin and Cressey 1962). Thus, in spite of the genesis of the value system, prison inmates who assimilate into the inmate subculture may have a much more difficult time to adjust to a normal life outside the prison walls (Irwin and Cressey 1962; Toch, Adams, and Grant 1989). This is why scholars usually referred to prisons institutions as "schools of crime" because the prison culture usually teaches and reinforces antisocial values and behaviours and at the 
same time increases the probability of criminal recidivism for individuals who are imprisoned (Gendreau et al., 1999; Nagin et al., 2009).

Stigma: Stigma according to Goffman (1963) is considered as 'mark' that discounts a person's credibility, endowing him/ her with detrimental characteristics (Link and Phelan 2001). In the case of ex prisoners, the mark of being an ex-convict endures long after their initial release from the prison. The stigma of stereotyping, labeling, discrimination, status loss, and separation (Link and Phelan 2001) experienced by ex-prisoners is considered as 'invisible punishment' (Henderson, 2005:1240). The challenges of stigma and reintegration is particularly challenging for offenders released from prison such as securing stable employment and being independent, when they are compared to others without incarceration (Uggen and Wakefield 2005). Hence, upon their re-entry they face and have to solve the problem of dual transition from inmate to citizen (Chung et al., 2005; Sullivan 2004).

Furthermore, stigma can be seen as a label placed on a particular individual or group that result in devaluation and also associated with undesirable characteristics. Though public stigma may be differed from self-stigma, in the sense that the former refer to the discrimination imposed by more powerful groups such as the community or government on the labelled group (Link and Phelan 2001) while the latter takes place when the minority group (as in the case of ex-prisoners), internalizes such beliefs against themselves (Corrigan and Watson, 2002; Mak and Cheung, 2010). Thus, once the negative label has been internalized, the labelled individual may adjust his/ her behaviours to match such new evaluations. In the case of Ex-prisoners such internalization will mean and justify their returning to deviant activities (Winnick and Bodkin, 2008). Moreover, self-stigma, involves perceptions of discrimination from others which can be seen from three major perspectives; stereotype (negative belief about individual ability), prejudice (showing of low self-esteem), and discrimination (artificial disparities in terms of employment and interaction) (Corrigan and Watson, 2002). Thus, self-stigma usually leads to profound negative consequences including lower self-esteem (LeBel, 2012), less social unity (Corrigan and Watson, 2002), and even poor health (Schnittker and John, 2007). Also apart from withdrawal and shame, stigmatized individuals may respond with aggression and anger which is evidently shown in criminological literatures. On one hand, it was argued that, the stigma of arrest and sanction transformed into shame and embarrassment, which can be seen as a deterrence for future law violations (Kobayashi et al., 2001; Kobayashi and Kerbo, 2012; Grasmick et al., 1991), while on the other hand, it was argued that stigma is harmful and leading to anger and resentment rather than shame and remorse, which increases the likelihood of recidivism (Chen, 2004; Funk, 2004; Vagg, 1998).

Discrimination: Discrimination of ex-prisoners is considered to be an offshoot of social stigma (Goffman, 1963). Generally, the perception of discrimination can be seen as a verdict that an individual has experienced one form of rejection, unequal, or unfair treatment because of being a member that belong to a particular disadvantaged social group (Kaiser \& Major, 2006) like the ex-prisoners. Many scholars in the area of criminal justice considered the plight of ex- felons as "a criminal conviction, no matter how trivial or how long ago it occurred as a dent or a scar on someone for life" (Petersilia, 2003, p. 19). However, it is well established that former prisoners suffer from many 'civil disabilities' as well as discriminations in many respects: public and private employment, voting, eligibility for public assistance and public housing, financial aid, education, parenting, and other familial issues and rights among other basic rights ( Legal Action Center, 2004; Mauer and Chesney-Lind, 2002; Travis, 2005). According to Pager (2007) discrimination base on person's race has a negative impact on employment prospects, that is, equal to or greater than the impact of having a criminal record. Simultaneously, the veracity of reentry is that many ex-prisoners returned to urban neighbourhoods with the highest levels of social and economic disadvantage (Clear, 2007; Travis, 2005) which leads to high rate of poverty and this is why Reiman (2004), contended that "the poor are seen as the real threat to decent society" and "the poverty of criminals makes poverty itself an individual moral crime!" (p. 173).

Personality: Personality traits and personal disposition of an individual represent a particular behaviour pattern and some studies suggested that criminal recidivism could be associated with such pattern of behaviour (Savage, 2009). Many studies have shown that the Big Five facets (John, Naumann \& Sotto, 2008) maintain constant and interpretable relations in terms of delinquency and criminal activity. That is to say, there is a negative correlation between crime, Agreeableness and Conscientiousness (Le Corff \& Toupin, 2009) and this suggested that criminal personality of an individual is characterized by violence, hostility and the inability to impede gratification. On the other hand, many scholars are of the view that, some individual personality traits and dispositions can produce delinquent as well as criminal behaviour. 
Such dispositions are considered to be the durable and stable individual internal dispositions that form and shape moral behavior and it symbolises a deep personality-related extraction of individual differences in terms of moral behaviour or otherwise. This concept is what Kneževic (2003) referred to Amorality, and it comprises of three main modalities: Amorality induced by impulsivity, Amorality induced by frustration, and Amorality induced by brutality (Kneževic et al., 2008). It is also argued that, the main aspects of Amorality is believed to have a negative limit of the honesty and humility trait (Ashton, Lee \& Son, 2000) and evidence also suggested that general amorality is normally linked to the most diverse aspects of criminal behavior (Mededovic et al., 2012) and it is also supported by Amorality induced by brutality and frustration.

\section{Conclusion}

This study was carried out on the ex-prisoners in metropolitan Kano, Nigeria. The study used four main constructs as predictors of criminal recidivism (prison, stigma, discrimination and personality). From the interview findings and analysis as reported, it is evident that, prison, stigma and discrimination are proved to have a positive effect toward recidivism as the interview from the ex-prisoners revealed which is further supported by the discussions. Though, from the discussion personality traits are considered to have effect towards reoffending but this is not the case for this study as the interview did not yield much about personality vis-a-vis recidivism. Therefore, it can be concluded that three of the predictors studied in Kano (prison, stigma and discrimination) are found to be among the predictors that determined criminal recidivism among the ex-prisoners in metropolitan Kano-Nigeria.

\section{Reference}

Ashton, M. C., Lee, K. \& Son, C. (2000). Honesty as the sixth factor of personality: Correlations with Machiavellianism, primary Psychopathy, and social adroitness. European Journal of Personality, 14(4), 359-368.

Beck, A. J. \& Shipley, B. E. (1989). Recidivism of prisoners released in 1983. Washington, DC: US Department of Justice, Bureau of Justice Statistics

Becker, G. S. (1968) Crime and Punishment: An Economic Approach. The Journal of Political Economy, 76, 169-217.

Bonta, J., Harman, W. G., Hann, R. G. \& Cormier, R. B. (1996). The Prediction of Recidivism among Federally Sentenced Offenders: A Re-Validation of the SIR Scale. The Canadian Journal of Criminology, 38, 61-72.

Broadhurst, R. G. \& Maller, R. A. (1990). The Recidivism of Prisoners Released for the First Time: Reconsidering the Effectiveness Question. Australian and New Zealand Journal of Criminology, 23, 88-104. 61-79

Cid, J. (2009). Is Imprisonment Criminogenic?: A comparative study of Recidivism Rates between Prison and Suspended Sanction. European Journal of Criminology, 6(6)459-480.

Cunliffe, J. \& Shepherd, A. (2007). Reoffending of Adults: Results from the 2004 Cohort. Home Office Statistical Bulletin 06 / 07. London: Home Office.

Corrigan, P. W. \& Watson, A. C. (2002). The paradox of self-stigma and mental illness. Clinical Psychology: Science and Practice, 9(1), 35-53.

Chen, X. (2004) Social and Legal Control in China: A Comparative Perspective. International Journal of Offender Therapy and Comparative Criminology, 48, 523-536.

Chung, H. L., Michelle, L. \& Laurence, S. (2005). The Transition to Adulthood for Adolescents in the Juvenile Justice System: A Developmental Perspective. 68-91 in On your Own without a Net: The Transition to Adulthood for Vulnerable Populations, edited by D. W. Osgood, E. M. Foster, C. Flanagan and G. R. Ruth. Chicago: The University of Chicago Press

Clear, T. R. (2007). Imprisoning communities: How mass incarceration makes disadvantaged neighbourhoods worse. New York, NY: Oxford University Press

Clemmer, D. (1940). The prison community. New York: Rinehart.

Clower, C. E. \& Bothwell, R. K. (2001). An Exploratory study of the relationship between the Big Five and inmate recidivism. Journal of Research in Personality, 35, 231-237.

Davis, C., Bahr, S. J. \& Ward, C. (2012). The Process of Offender Reintegration: Perception of what helps the Prisoner to re-enter society. Criminology and Criminal Justice, 13(4), 446-469.

Di Tella, R. \& Schargrodsky, E. (2010). Criminal recidivism after prison and electronic monitoring. NBER Working Paper No. 15602.

Farrall, S. \& Sparks, R. (2006). Introduction. Criminology and Criminal Justice, 6(1), 7-17 
Farrall, S. \& Sparks, R. (2006). Introduction to Special Issue on Problems, Prospects and Possibilities for Life after Punishment. Criminology and Criminal Justice, 6(1), 7-17.

Funk, P. (2004). On the effective use of stigma as a crime-deterrent. European Economic Review, 48(4), 715-728.

Francis, T. C., Jonson, C. L. \& Nagin, D. S. (2011). Prisons Do not Reduce Recidivism: The high cost of ignoring Science. The prison Journal, 91(3), 485-655.

Gendreau, P., Little, T. \& Goggin, C. (1996). A Meta-Analysis of the Predictors of Adult Offender Recidivism: What Works! Criminology, 34(4), 575-607.

Gendreau, P., Goggin, C. \& Cullen, F. T. (1999) The Effects of Prison Sentences on Recidivism. Ottawa, ON: Solicitor General Canada

Goffman, E. (1963). Stigma: Notes on the Management of Spoiled Identity. Englewood Cliffs, NJ: Prentice Hall

Grasmick, H. G. \& Bursik, R. J. (1990). Conscience, Significant Others, and Rational Choice: Extending the Deterrence Model. Law and Society Review, 24, 837-61

Grasmick, H. G., Bursik, R. J. \& Kinsey, K. A. (1991). Shame and embarrassment as deterrents to noncompliance with the law the case of an antilittering campaign. Environment and Behavior, 23(2), 233-251.

Hare, R. D. (1999). The Hare Psychopathy Checklist-Revised: PLC-R. MHS, Multi-Health Systems.

Henderson, T. N. Y. (2005). New frontiers in fair lending: Confronting lending discrimination against exoffenders. New York University Law Review, 80, 1237.

Huebner, B. M. \& Berg, M. T. (2011). Examining the sources of variation in risk for recidivism. Justice Quarterly, 28(1), 146-173.

Irwin, J. \& Cressey, D. (1962). Thieves, Convicts, and the Inmate Culture. Social Problems, 10, 142-5

John, O. P., Naumann, L. P. \& Soto, C. J. (2008). Paradigm shift to the integrative Big-Five trait taxonomy: History, measurement, and conceptual issues. In O. P. John, R. W. Robins, \& L. A. Pervin (Eds.), Handbook of Personality: Theory and Research, 3rd ed. (pp. 114- 158). New York, NY: Guilford Press

Kaiser, C. R. \& Major, B. (2006). A social psychological perspective on perceiving and reporting discrimination. Law \& Social Inquiry, 31(4), 801-830.

Kobayashi, E. \& Kerbo, H. R. (2012). Differences in Perceived Levels of Informal Punishments for Noncompliance and Rewards for Compliance: A Comparison of Japanese and American Workers. Deviant Behavior, 33(1), 40-57.

Kobayashi, E., Grasmick, H. \& Friedrich, G. (2001). A cross-cultural study of shame, embarrassment, and management sanctions as deterrents to noncompliance with organizational rules. Communication Research Reports, 18(2), 105-117.

Koschmann, M. A. \& Pertason, B. L. (2013). Rethinking Recidivism: A communication Approach to prison Re-entry. Journal of Applied Social Sciences, 7(2), 188-207.

Kneževic, G., Radovic, B. \& Perunicic, I. (2008). Can Amorality Be Measured? 14th European Conference on Personality, Tartu, Estonia, July 16-20, 2008, Book of Abstracts, p. 137.

Kneževic, G. (2003). Koreni amoralnosti [The Roots of Amorality]. Beograd: Institut za kriminološka i sociološka istraživanja, Institut za psihologiju.

Langan, P. \& Levin, D. (2002). Recidivism of Prisoners Released in 1994.Washington, DC: US Department of Justice, Bureau of Justice Statistics.

Langevin, R. \& Curnoe, S. (2011). Psychopathy, ADHD, and Brain Dysfunction as predictors of Life time Recidivism among Sex Offenders. International Journal of Offender Therapy and Comparative Criminology, 55(1), 5-26.

LeBel, T. P (2012). If One Doesn't Get You Another One Will': Formerly Incarcerated Persons' Perceptions of Discrimination. The Prison Journal, 92, 63-87

LeBel T. P., Burnett, R., Maruna, S. \& Bushway, S. (2008). The 'Chicken and Egg' of Subjective and Social Factors in Desistance from Crime. European Journal of Criminology, 5(2), 131-159.

Le Corff, Y. \& Toupin, J. (2009). Comparing persistent juvenile delinquents and normative peers with the Five-Factor Model of Personality. Journal of Research in Personality, 43(6), 1105-1108.

Legal Action Center. (2004). After prison: Roadblocks to reentry: A report on state legal barriers facing people with criminal records. New York, NY: Author.

Lemert, E. M. (1972). Human Deviance, Social Problems, and Social Control (2 ${ }^{\mathrm{rm} "}$ Ed). Englewood Cliffs, NJ.

Link, B. G. \& Phelan, J. C. (2001). Conceptualizing stigma. Annual review of Sociology, 2, 363-385.

Lloyd, C., Mair, G. \& Hough M. (1994). Explaining Reconviction Rates: A Critical Analysis. Home Office Research Study No. 136. London: HMSO. 
Mauer, M. \& Chesney-Lind, M. (2002). Invisible punishment: The collateral consequences of mass imprisonment. New York, NY: The New Press.

Madaki, M. (2011). A Study of the Legal Rights of Convicted Prisoners and the Unintended Consequences of Incarceration in Kano Central and G/dutse Prisons, Nigeria. Unpublished PhD Dissertation Submitted to the Department of Sociology, Bayero University, Kano.

Mak, W. W. \& Cheung, R. Y. (2010). Self-Stigma among Concealable Minorities in Hong Kong: Conceptualization and Unified Measurement .American Journal of Orthopsychiatry, 80(2), 267281.

Makarios, M., Steiner, B. \& Travis, L. F. (2010). Examining the predictors of recidivism among men and women released from prison in Ohio. Criminal Justice and Behavior, 37, 1377-1391.

Međedović, J., Kujačić, D. \& Knežević, G. (2012). Personality-related determinants of criminal recidivism. Psihologija, 45(3), 277-294.

Meade, B., Steiner, B., Makarious, M. \& Travis, L. (2012). Estimating a Dose- Response Relationship between Time Served in Prison and Recidivism. Journal of Research in Crime and Delinquency, 50(4), 525550.

Nagin, D, F. Cullen, T. \& Cheryl, L. J. (2009). Imprisonment and Reoffending. Pp. 115-200 in Crime and Justice: A Review of Research, Vol. 38, edited by M. Tonry. Chicago, IL: University of Chicago Press

Nagin, D. (1998). Criminal Deterrence Research at the Outset of the Twenty-first Century. Pp. 1-42 in Crime and Justice: A Review of Research, Vol. 23, edited by M. Tonry. Chicago, IL: University of Chicago Press

National Research Council. (2007). Parole, desistance from crime, and community integration. Washington, DC: Committee on Community Supervision and Desistance from Crime, National Academy of Sciences Press.

Petersilia, J. (2003). When prisoners return to communities: Political, economic and social consequences. New York: Oxford University Press.

Reiman, J. (2004). The rich get richer and the poor get prison: Ideology, class, and criminal justice (7th ed.). Boston, MA: Pearson

Savage, J. (2009). Understanding persistent offending: linking developmental psychology with research on the criminal career. In: J. Savage, (ed.), The Development of Persistent Criminality (pp. 3-33). Oxford: Oxford University Press

Sullivan, M. L. (2004). Youth perspectives on the experience of reentry. Youth Violence and Juvenile Justice, 2(1), 56-71.

Schnittker, J. \& John, A. (2007). Enduring stigma: the long-term effects of incarceration on health. Journal of Health and Social Behavior, 48(2), 115-130.

Sykes, G. M. (1958). The Society of Captives. Princeton, NJ: Princeton University Press.

Steen, S. \& Opsal, T. (2007). Punishment on the Instalment Plan Individual-Level Predictors of Parole Revocation in Four States. The Prison Journal, 87(3), 344-366.

Tenibiaje, D. J. (2013). Educational Attainment and Peer Group Influence as Predictors of Recidivism. International Review of Social Sciences and Humanities, 5(1), 30-37.

Toch, H., Adams, K. \& Grant, J. D. (1989). Coping: Maladaptation in Prisons. New Brunswick, NJ: Transaction

Travis, J., Solomon, A. L. \& Waul, M. (2001). From Prison to Home: The Dimensions and Consequences of Prisoner Reentry. Washington, DC: Urban Institute Press.

Travis, J. (2005). But they all come back: Facing the challenges of prisoner reentry. Washington, DC: The Urban Institute Press.

Uggen, C. \& Wakefield, S. (2005). Young Adults Re-entering the Community from the Criminal Justice System: The Challenge of Becoming an Adult. Pp. 114-144 in On your Own without a Net: The Transition to Adulthood for Vulnerable Populations, edited by D. W. Osgood, E. M. Foster, C. Flanagan, and G. R. Ruth. Chicago: The University of Chicago Press.

Vagg, J. (1998). Delinquency and shame data from Hong Kong. British Journal of Criminology, 38(2), 247264.

Van Olphen, J., Eliason, M. J., Freudenberg, N. \& Barnes, M. (2009). Nowhere to go: How stigma limits the options of female drug users after release from jail. Substance Abuse Treatment, Prevention, \& Policy, 4, 1-10. Retrieved from http:// www.substanceabusepolicy.com/content/pdf/1747597X-4-10.pdf

Visher, C. A. \& Travis, J. (2003). Transitions from prison to community: Understanding individual pathways. Annual Review of Sociology, 2, 89-113. 
Van Vugt, E., Gibbs, J., Stams, G. J., Bijleveld, C., Hendriks, J. \& van der Laan, P. (2011). Moral Development and Recidivism A Meta-Analysis. International journal of offender therapy and comparative criminology, 55(8), 1234-1250.

Waldfogel, J. (1994). The Effect of Criminal Conviction on Income and the Trust Reposed on Workmen. Journal of Human Resources, 29, 62-81.

Wartna, B. S. J. \& Nijssen, L. T. J. (2006). National Studies on Recidivism: An Inventory of Large-Scale Recidivism Research in 33 European Countries. The Hague: WODC

Wehrman, M. M. (2010). Race, concentrated disadvantage, and recidivism: A test of interaction effects. Journal of Criminal Justice, 38(4), 538-544.

Winnick, T. A. \& Bodkin, M. (2008). Anticipated stigma and stigma management among those to be labelled "ex-con". Deviant Behavior, 29(4), 295-333. 